\title{
THE TMAI MODEL - PERFORMANCE OF PORTFOLIOS CONSTRUCTED ON THE BASE OF CORRELATED AND UNCORRELATED FINANCIAL RATIOS
}

Tomasz Węgrzyn, Ph.D.

University of Economics in Katowice

Department of Applied Mathematics

1 Maja 50, 40-287 Katowice

Email: tomasz.wegrzyn@ue.katowice.pl

Received 10 February 2014, Accepted 24 October 2014

\begin{abstract}
The author studies portfolio performance. Companies are chosen to portfolios due to their position in the ranking that is constructed on the base of the chosen financial ratios. There are three rankings constructed on different number of financial ratios. Each ranking is constructed on the base of synthetic measure of development. The TMAI ranking is constructed on the base of 48 financial ratios, the TMAI_gr1 ranking is constructed on the base of 14 financial ratios that can be correlated and the TMAI_gr2 ranking is constructed on the base of 8 uncorrelated financial ratios. The author uses data of companies listed on the Warsaw Stock Exchange between 2005 and 2011. The rankings and portfolios are built separately for each year. As a result, it can be stated that the Portfolio 3 in the TMAI_gr1 ranking is the best portfolio for investors who are maximizing the Sharpe ratio.
\end{abstract}

Keywords: financial ratios, stock selection, synthetic measure of development, the Sharpe ratio, the Omega ratio.

JEL classification: C38, G11, G32. 


\section{Introduction}

The synthetic measure of development $(\mathrm{SMD})^{1}$ is one of the methods of linear arrangement. It enables the classification of companies in relation to the set variables. In company analysis, the value of the SMD points out the financial strength of companies. Tarczyński ${ }^{2}$ has been the first one to propose using the SMD in order to construct securities portfolio on account of their financial strength. He introduced the notion of TMAI that is Taxonomic Measure Attractiveness of Investment ${ }^{3}$. The possibility of using the TMAI was examined in details by Tarczyński, Łuniewska, Hadaś-Dyduch and Węgrzyn ${ }^{4}$.

The TMAI model ${ }^{5}$ allows to arrange companies by their financial condition. As a result a ranking of companies is constructed. The ranking can be used in order to point out companies for portfolio e.g. companies with the highest position in the ranking. They can be used in the construction of more complex financial instruments, for example structured products ${ }^{6}$. The position of the company in the ranking depends on financial ratios used in the construction of the SMD. Financial ratios should be chosen on account of information concerning each financial ratio. Moreover, during selection of the financial ratios to the SMD, the level of their correlation should be considered.

Jerzemowska points out four areas of a company activity ${ }^{7}$. Each area of a company activity is described by some financial ratios $^{8}$. Węgrzyn studies the correlation of 48 financial ratios that describe each area of a company activity ${ }^{9}$. He points out that the highest correlation is between financial ratios that describe the same area of a company activity. However, some financial ratios that describe separate area of a company activity are also significantly correlated. As a result, Węgrzyn suggests that we should not use all 48 analysed financial rations in the construction of SMD. Węgrzyn proposes ${ }^{10}$ to construct the SMD on the base of one of two groups of financial ratios:

- group 1: 14 financial ratios that are not significantly correlated with other financial ratios inside the same area of a company activity, but they can be significantly correlated with other financial ratios that describe another area of a company activity,

- group 2: 8 financial ratios that are not significantly correlated with any other financial ratio.

The purpose of the article is the analysis of portfolio performance on account of the correlation of financial ratios. Companies are chosen to portfolios due to their position in the ranking that is constructed on the base of the chosen group of financial ratios. Each group of 
financial ratios is characterised by a different level of correlation. Three rankings of companies are constructed on account of the level of correlation:

- the TMAI ranking: the ranking constructed on the base of all financial ratios regardless of the level of their correlation (48 financial ratios are used),

- the TMAI_gr1 ranking: the ranking constructed on the base of financial ratios from the group 1 (14 financial ratios are used),

- the TMAI_gr2 ranking: the ranking constructed on the base of financial ratios from the group 2 (8 financial ratios are used).

\section{Relative growth rate - definition}

Among the analysed financial ratios there are ones that can be positive or negative. Therefore, in order to compute the relative growth rate, the following formula is used ${ }^{11}$ :

$$
\delta=\frac{\Delta W_{t_{1}}}{\left|W_{t_{0}}\right|}=\left\{\begin{array}{l}
\frac{W_{t_{1}}-\left|W_{t_{0}}\right|}{\left|W_{t_{0}}\right|} \text { when } \quad W_{t_{1}}<0 \wedge W_{t_{0}}<0 \\
\frac{W_{t_{1}}-W_{t_{0}}}{\left|W_{t_{0}}\right|} \text { when } W_{t_{0}} \neq 0
\end{array}\right.
$$

where:

$W_{t 1}$ - value of the financial ratio in the current year,

$W_{t 0}-$ value of the financial ratio in the previous year (the base year).

Values that are produced by the formula (1) cannot be explicitly interpreted. They can be interpreted only when the financial ratio for two consecutive years is positive. Moreover, when financial ratio for the base year $\left(\mathrm{W}_{\mathrm{t} 0}\right)$ is equal to zero then a relative growth rate cannot be computed. The proposed method of computing the relative growth rate can be used when among the analysed data such financial ratios can be found that are negative (e.g. loss) or positive (eg. profit) and:

- increase and decrease of losses (negative values) is negatively assessed,

- decrease of profits (positive values) is negatively assessed,

- increase of profits (positive values) is positively assessed,

- profits instead of losses are positively assessed ${ }^{12}$. 


\section{Chosen financial ratios}

In the study the following financial ratios and the relative growth rate of financial ratios are used:

\section{A. Profitability ratios:}

- ROE - return on equity ${ }^{13}$,

- $\mathrm{ROA}$ - return on assets $^{14}$,

- ROS - return on sales ${ }^{15}$,

- Mzbs - gross return on sales ${ }^{16}$,

- Mzop - operating profit on sales ${ }^{17}$,

- Mzb - gross profit margin ${ }^{18}$,

- $\triangle \mathrm{ROE}$ - relative growth rate of $\mathrm{ROE}$,

- $\triangle \mathrm{ROA}$ - relative growth rate of ROA,

- $\triangle \mathrm{ROS}$ - relative growth rate of ROS,

- $\Delta \mathrm{Mzbs}-$ relative growth rate of Mzbs,

- $\Delta$ Mzop - relative growth rate of Mzop,

- $\Delta \mathrm{Mzb}$ - relative growth rate of Mzb,

- $\Delta \mathrm{Zn}$ - relative growth rate of net income,

- $\Delta$ Zop - relative growth rate of operating income,

$-\Delta \mathrm{Ps}-$ relative growth rate of net sales.

\section{B. Liquidity ratios:}

- Wpb - current ratio ${ }^{19}$,

- Wps - quick ratio ${ }^{20}$,

- Wpp - cash ratio ${ }^{21}$,

- RGS - operating cash flow on sales ${ }^{22}$,

- RGZ - net profit on operating cash flow ${ }^{23}$,

$-\Delta \mathrm{Wpb}$ - relative growth rate of $\mathrm{Wpb}$,

- $\Delta \mathrm{Wps}$ - relative growth rate of $\mathrm{Wps}$,

- $\Delta \mathrm{Wpp}$ - relative growth rate of $\mathrm{Wpp}$,

- $\Delta \mathrm{RGS}$ - relative growth rate of RGS,

- $\Delta \mathrm{RGZ}$ - relative growth rate of $\mathrm{RGZ}$,

- $\Delta \mathrm{Gop}$ - relative growth rate of operating cash flow ${ }^{24}$.

C. Asset turnover ratios (activity ratios or efficiency ratios):

- RA - asset turnover in days ${ }^{25}$, 
- $\mathrm{RNal}$ - receivables conversion period (in days) ${ }^{26}$,

- RZap - inventory conversion period (in days) ${ }^{27}$,

- Cop - operating cycle (in days) ${ }^{28}$,

- RZob - payables conversion period (in days) ${ }^{29}$,

- CKG - Cash Conversion Cycle ${ }^{30}$,

- RMO - current assets turnover in days ${ }^{31}$,

$-\Delta \mathrm{RA}-$ relative growth rate of RA,

- $\triangle \mathrm{RNal}$ - relative growth rate of RNal,

- $\Delta$ RZap - relative growth rate of RZap,

$-\Delta \mathrm{Cop}-$ relative growth rate of Cop,

- $\Delta$ Rzob - relative growth rate of Rzob,

- $\triangle \mathrm{CKG}$ - relative growth rate of $\mathrm{CKG}$,

- $\triangle \mathrm{RMO}$ - relative growth rate of RMO.

\section{Financial leverage ratios (debt ratios):}

- Szo - debt ratio ${ }^{32}$,

- WPM - equity to fixed assets,

- WOZ - sum of depreciation and financial costs to net profit ${ }^{33}$,

- WPZ - current liabilities to sum of annual interest expense and depreciation,

$-\Delta \mathrm{Szo}-$ relative growth rate of Szo,

$-\triangle \mathrm{WPM}-$ relative growth rate of WPM,

$-\triangle \mathrm{WOZ}-$ relative growth rate of $\mathrm{WOZ}$,

$-\triangle \mathrm{WPZ}$ - relative growth rate of WPZ.

\section{Synthetic measure of development}

The synthetic measure of development (SMD) is one of the methods of linear arrangement. It enables the classification of companies in relation to the set variables ${ }^{34}$. In company analysising, the value of the SMD points out the financial strength of companies ${ }^{35}$. The SMD for a given company is computed as follows ${ }^{36}$ :

$$
\operatorname{TMAI}_{i}=1-\frac{d_{i}}{d_{0}}
$$

where:

$d_{i}-$ Euclidean distance between the company and the model object given by the formula: 


$$
d_{i}=\sqrt{\sum_{j=1}^{m} \frac{1}{m} \cdot\left(z_{j}-z_{0 j}\right)^{2}}
$$

$z_{i j}$ - value of the $j^{\text {th }}$ variable for $i^{\text {th }}$ company (after standardisation)

$z_{0 j}$ - value of the $j^{\text {th }}$ variable for the model object:

$$
z_{0 j}=\max _{j=1}^{m}\left(z_{j}\right)
$$

$d_{0}$ - the norm that guarantees the value of TMAI between 0 and 1 :

$$
d_{0}=\max \left(d_{0 j}\right)
$$

As it can be noticed from the equation (3), it has been assumed that each financial ratio has the same weight in the SMD.

Variables (financial ratios) are divided into stimulants and destimulants. Stimulants are those financial ratios for which an increase is assessed positively, whereas destimulants are those financial ratios for which an increase is assessed negatively. Then variables (both stimulants and destimulants) are standardised.

\section{Assumptions}

In the study covers the nonfinancial companies that were listed on the WSE between 04.2005 and 04.2012. They are included, in the end of March of a given year, in one of the following indexes: WIG20, $\mathrm{mWIG} 40^{37}$ or $\mathrm{sWIG} 80^{38}$. From among such companies the following are excluded:

- banks, insurances companies and lease companies,

- companies included in the following sectors: finance or finance-other,

- companies for which there is no full financial statements for two preceding years ${ }^{39}$,

- companies that have negative value of the shareholders equity in the balance sheet (that is used in order to compute financial ratios),

- companies that have value of revenues from sales equal to zero in the income statement (that is used in order to compute financial ratios).

As the result, in the consecutive years there are between 108 and 118 companies qualified for the study. The number of companies qualified for the study in a given year is shown in the Table 1. 
Table 1. The number of companies qualified for the study in the consecutive years

\begin{tabular}{|l|c|c|c|c|c|c|c|}
\hline Year & 2005 & 2006 & 2007 & 2008 & 2009 & 2010 & 2011 \\
\hline Number of companies & 108 & 105 & 106 & 113 & 117 & 118 & 116 \\
\hline
\end{tabular}

Source: own study.

For each company qualified for the study in a given year the financial ratios described in the section 2 are computed. In order to compute the financial ratios the financial statements for a previous year are used. It means that historical values of financial ratios are used. The values of financial ratios are used to the construction of the SMD.

In the study, the impact of the correlation of financial ratios on portfolio performance is analysed, if the portfolio is constructed on account of the SMD. In order to analyse it, three rankings are constructed:

a) The TMAI ranking - constructed on account of all financial ratios pointed out in the section 2 of the article;

b) The TMAI_gr1 ranking ${ }^{40}$ - constructed on account of 14 financial ratios:

- profitability ratios: $\mathrm{ROE}, \Delta \mathrm{Ps}, \Delta \mathrm{Mzb}$,

- liquidity ratios: $\mathrm{Wpb}, \Delta \mathrm{Gop}, \mathrm{RGZ}, \Delta \mathrm{Wpp}$,

- asset turnover ratios: Rzap, $\Delta \mathrm{Rzob}, \Delta \mathrm{CKG}$,

- financial leverage ratios: WPM, WPZ, $\Delta \mathrm{Szo}, \Delta \mathrm{Woz}$;

c) The TMAI_gr2 ranking ${ }^{41}$ - constructed on account of 8 financial ratios:

- profitability ratios: ROE, $\Delta \mathrm{Ps}, \Delta \mathrm{Mzb}$,

- liquidity ratios: $\mathrm{RGZ}, \Delta \mathrm{Wpp}$,

- asset turnover ratios: $\triangle \mathrm{CKG}$,

- financial leverage ratios: WPM, $\triangle$ Woz.

The position of the company in each ranking separately allows to assign it into one of five quantile portfolios in the following way:

- into the first portfolio, $20 \%$ of companies with the highest position are put,

- into the second portfolio, the next $20 \%$ of companies with the highest position are put that are not included in the first portfolio,

- into the third portfolio, the next $20 \%$ of companies with the highest position are put that are not included in the first or second portfolio,

- into the fourth portfolio, the next $20 \%$ of companies with the highest position are put that are not included in the first or second or third portfolio,

- into the fifth portfolio, the remaining companies are put. 
As the result, five equipotent portfolios for each ranking are constructed. Each portfolio is bought during the last session in the first week of April in a given year and sold during the last session in the first week of April next year. In each company 10,000 PLN is invested, the quantity of stocks is rounded down to integer and it is constant during the investment period.

In the study the financial companies like banks, insurance companies and lease companies are not included. As the result, the index WIG or any other index cannot be a benchmark. The benchmark portfolio (BP) is constructed like other portfolios. In the BP all companies qualified for a study in the given year are included. In each company 10,000 PLN is invested, the quantity of stocks is rounded down to integer. The quantity of stocks is constant during the investment period.

Assessment of each portfolio is done by:

- average geometric rate of return for an seven-years-period of investment $\left(R_{G}\right)$,

- cumulated rate of return $\left(\mathrm{R}_{\text {cum }}\right)$,

- investment rate of return,

- a Sharpe ratio ${ }^{42}$,

- an Omega ratio ${ }^{43}$.

\section{Performance analysis}

There are investment rates of return for each constructed portfolio between 2005 and 2011 in the Table 2. In case of the TMAI ranking, the comparison of returns achieved by each portfolio with the return for the BP points out that the Portfolio 2 the most frequently gives the rate of return that is higher than the rate of return for the BP (that situation occurs 6 times during 7 years). Whereas, in case of the TMAI_gr1 ranking that situation is for the Portfolio 2 and the Portfolio 3 ( 5 times during 7 years the portfolio gives higher rate of return than the BP). In case of the TMAI_gr2 ranking that situation is for the Portfolio 2 and the Portfolio 3 (4 times during 7 years).

In the Table 3, there are cumulated rates of return, geometric average rates of return and the Sharpe ratios for constructed portfolios. In case of the TMAI ranking the Portfolio 2 gives the highest $R_{G}$, that is $7.3 \mathrm{pp}^{44}$ higher than the $\mathrm{R}_{\mathrm{G}}$ for the BP. As the result, the $\mathrm{R}_{\text {cum }}$ for the Portfolio 2 is more than 2 times higher than it is for the BP. While, in case of the TMAI_gr1 ranking, the Portfolio 3 gives the highest $R_{G}$, that is 13.1 pp higher than the $R_{G}$ for the BP. As a consequence, the $\mathrm{R}_{\text {cum }}$ for the Portfolio 3 is more than 3.5 times higher than it is for the BP. In case of the TMAI_gr2 ranking, the Portfolio 2 gives the highest $\mathrm{R}_{\mathrm{G}}$, that is $13.5 \mathrm{pp}$ above the 
$\mathrm{R}_{\mathrm{G}}$ for the BP. As a result, the $\mathrm{R}_{\text {cum }}$ for the Portfolio 2 is also more than 3.5 times higher than it is for the BP. The comparison of the $\mathrm{R}_{\mathrm{G}}$ for that three portfolios points out that the $\mathrm{R}_{\mathrm{G}}$ for the Portfolio 2 in the TMAI_gr2 ranking is the highest.

Table 2. Investment rate of return for constructed portfolios ( $\%)$

\begin{tabular}{|c|c|c|c|c|c|c|c|c|}
\hline \multicolumn{2}{|c|}{ Year } & 2005 & 2006 & 2007 & 2008 & 2009 & 2010 & 2011 \\
\hline \multicolumn{2}{|c|}{ Benchmark portfolio } & 143 & 82 & -28 & -55 & 61 & 7 & -23 \\
\hline \multirow{5}{*}{$\sum_{i}^{\mathbb{Z}}$} & Portfolio 1 & 372 & 79 & -29 & -63 & 49 & 29 & -41 \\
\hline & Portfolio 2 & 150 & 122 & -16 & -53 & 74 & 8 & -27 \\
\hline & Portfolio 3 & 99 & 72 & -30 & -49 & 63 & 2 & -12 \\
\hline & Portfolio 4 & 66 & 105 & -32 & -55 & 71 & -6 & -18 \\
\hline & Portfolio 5 & 38 & 34 & -34 & -54 & 47 & 1 & -19 \\
\hline \multirow{5}{*}{ 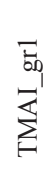 } & Portfolio 1 & 137 & 72 & -22 & -59 & 44 & 31 & -37 \\
\hline & Portfolio 2 & 68 & 119 & -27 & -52 & 83 & 12 & -29 \\
\hline & Portfolio 3 & 347 & 101 & -21 & -49 & 58 & -5 & -21 \\
\hline & Portfolio 4 & 110 & 73 & -31 & -56 & 61 & 6 & -10 \\
\hline & Portfolio 5 & 49 & 48 & -39 & -57 & 58 & -9 & -19 \\
\hline \multirow{5}{*}{ 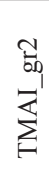 } & Portfolio 1 & 63 & 139 & -22 & -62 & 39 & 14 & -36 \\
\hline & Portfolio 2 & 352 & 65 & -12 & -48 & 61 & 7 & -27 \\
\hline & Portfolio 3 & 85 & 79 & -28 & -46 & 67 & -2 & -18 \\
\hline & Portfolio 4 & 143 & 71 & -39 & -55 & 78 & -1 & -19 \\
\hline & Portfolio 5 & 78 & 57 & -39 & -62 & 58 & 17 & -17 \\
\hline
\end{tabular}

Source: own study.

Table 3. Cumulated rate of return, geometric average rate of return (\%) and the Sharpe ratio

\begin{tabular}{|c|c|c|c|c|}
\hline & \multirow{3}{*}{$\begin{array}{c}\text { Cumulated rate } \\
\text { of return }\end{array}$} & \multirow[b]{2}{*}{$\begin{array}{c}\text { Geometric average } \\
\text { rate of return }\end{array}$} & \multirow[b]{2}{*}{ The Sharpe ratio } \\
\hline & & & & \\
\hline Benc & amark portfolio & & 9.6 & 0.18 \\
\hline \multirow{5}{*}{$\sum_{i}^{\bigotimes}$} & Portfolio 1 & 156 & 14.4 & 0.24 \\
\hline & Portfolio 2 & 198 & 16.9 & 0.41 \\
\hline & Portfolio 3 & 75 & 8.4 & 0.14 \\
\hline & Portfolio 4 & 40 & 4.9 & 0.00 \\
\hline & Portfolio 5 & -32 & -5.3 & -0.45 \\
\hline \multirow{5}{*}{$\sum_{\vec{E}}^{\overrightarrow{b_{0}}}$} & Portfolio 1 & 55 & 6.5 & 0.05 \\
\hline & Portfolio 2 & 84 & 9.1 & 0.15 \\
\hline & Portfolio 3 & 320 & 22.7 & 0.53 \\
\hline & Portfolio 4 & 70 & 7.9 & 0.12 \\
\hline & Portfolio 5 & -33 & -5.5 & -0.44 \\
\hline \multirow{5}{*}{ 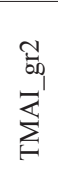 } & Portfolio 1 & 16 & 2.1 & -0.09 \\
\hline & Portfolio 2 & 328 & 23.1 & 0.52 \\
\hline & Portfolio 3 & 73 & 8.2 & 0.13 \\
\hline & Portfolio 4 & 62 & 7.1 & 0.08 \\
\hline & Portfolio 5 & -1 & -0.1 & -0.20 \\
\hline
\end{tabular}

Source: own study. 
When the Sharpe ratios are analysed, it can be found that in case of the TMAI ranking the highest Sharpe ratio is for the Portfolio 2. While, in case of the TMAI_gr1 ranking the highest Sharpe ratio is for the Portfolio 3. Whereas, in case of the TMAI_gr2 ranking the highest Sharpe ratio is for the Portfolio 2. Between that three portfolios, the highest Sharpe ratio is for the portfolio 3 in the TMAI_gr1 ranking. However the difference between the Sharpe ratio of the Portfolio 3 in the TMAI_gr1 ranking and the Portfolio 2 in the TMAI_gr2 ranking is 0.01. It means that the performance of that two portfolios is almost the same.

In the Table 4, there are Omega ratios for constructed portfolios. The omega ratios are computed for chosen break-even points $\mathrm{L}$, that is $0 \%, 4.77 \%, 10 \%, 15 \%, 20 \%, 25 \%$. Each rate that is considered as a break-even point is the logarithmic year rate. The break-even point $\mathrm{L}=4.77 \%$ is equal to the average risk free rate in the analysed period. In case of the TMAI ranking the highest Omega ratio is for the Portfolio 2. It is above 1 up to the breakeven point $\mathrm{L}=15 \%$. While, in case of the TMAI_gr1 ranking the highest Omega ratio is for the Portfolio 3. It is above 1 up to the break-even point $\mathrm{L}=20 \%$. Whereas, in case of the TMAI_gr2 ranking the highest Omega ratio is for the portfolio 2. It is above 1 up to the breakeven point $\mathrm{L}=20 \%$. It can be found that for each value of break-even point $\mathrm{L}$ the Omega ratios for the Portfolio 3 (the TMAI_gr1) and the Portfolio 2 (the TMAI_gr2) are higher than for the Portfolio 2 (the TMAI), which means that they are preferred to the Portfolio 2 (the TMAI). It can

Table 4. The Omega ratio for constructed portfolios

\begin{tabular}{|c|c|c|c|c|c|c|c|}
\hline \multicolumn{2}{|c|}{ Break-even point } & $\mathrm{L}=0 \%$ & $\mathrm{~L}=4,77 \%{ }^{*}$ & $\mathrm{~L}=10 \%$ & $\mathrm{~L}=15 \%$ & $\mathrm{~L}=20 \%$ & $\mathrm{~L}=25 \%$ \\
\hline \multicolumn{2}{|c|}{ Benchmark portfolio } & 1.16 & 1.07 & 0.99 & 0.91 & 0.84 & 0.77 \\
\hline \multirow{5}{*}{$\sum_{i}^{\rightleftarrows}$} & Portfolio 1 & 1.16 & 1.10 & 1.04 & 0.98 & 0.93 & 0.88 \\
\hline & Portfolio 2 & 1.25 & 1.17 & 1.08 & 1.01 & 0.94 & 0.87 \\
\hline & Portfolio 3 & 1.14 & 1.05 & 0.97 & 0.89 & 0.82 & 0.76 \\
\hline & Portfolio 4 & 1.09 & 1.00 & 0.91 & 0.84 & 0.77 & 0.71 \\
\hline & Portfolio 5 & 0.91 & 0.84 & 0.77 & 0.70 & 0.64 & 0.59 \\
\hline \multirow{5}{*}{$\begin{array}{l}\overrightarrow{b_{0}} \\
\overrightarrow{\mid} \\
\sum_{E}\end{array}$} & Portfolio 1 & 1.08 & 1.02 & 0.95 & 0.89 & 0.84 & 0.78 \\
\hline & Portfolio 2 & 1.14 & 1.06 & 0.98 & 0.91 & 0.84 & 0.78 \\
\hline & Portfolio 3 & 1.35 & 1.26 & 1.17 & 1.08 & 1.01 & 0.93 \\
\hline & Portfolio 4 & 1.13 & 1.05 & 0.96 & 0.89 & 0.82 & 0.75 \\
\hline & Portfolio 5 & 0.91 & 0.84 & 0.77 & 0.71 & 0.65 & 0.60 \\
\hline \multirow{5}{*}{ 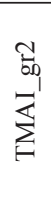 } & Portfolio 1 & 1.03 & 0.97 & 0.90 & 0.84 & 0.79 & 0.74 \\
\hline & Portfolio 2 & 1.34 & 1.25 & 1.16 & 1.08 & 1.01 & 0.94 \\
\hline & Portfolio 3 & 1.14 & 1.05 & 0.96 & 0.89 & 0.81 & 0.75 \\
\hline & Portfolio 4 & 1.11 & 1.03 & 0.95 & 0.88 & 0.82 & 0.76 \\
\hline & Portfolio 5 & 1.00 & 0.92 & 0.85 & 0.78 & 0.72 & 0.67 \\
\hline
\end{tabular}

${ }^{*}$ Average risk free rate in analysed period.

Source: own study. 
be also found, that for each value of break-even point $\mathrm{L}$ the Omega ratios for the Portfolio 2 (the TMAI_gr1) and the Portfolio 3 (the TMAI_gr2) are almost the same. It means that the performance of that two portfolios is almost the same.

\section{Conclusions}

The article is an attempt to point out the set of financial ratios that should be used in the process of stock selection to the portfolio. Three sets of financial ratios are studied: all financial ratios (they are used in the construction of the TMAI ranking), the group 1 of financial ratios are used in the construction of the TMAI_gr1 ranking (there are 14 financial ratios that are not significantly correlated with other financial ratios inside the same area of a company activity, but they can be significantly correlated with other financial ratios, that describe another area of a company activity) and the group 2 of financial ratios are used in the construction of the TMAI_gr2 ranking (there are 8 financial ratios that are not significantly correlated with any other financial ratio).

As the result, it can be stated that when returns are examined, then the Portfolio 2 in the TMAI_gr2 ranking is the best one. It means that when the investor is maximizing the return (for example the constructed portfolio will be mixed with the index portfolio), he or she should choose the Portfolio 2 in the TMAI_gr2 ranking. As the result he or she should use 8 non correlated financial ratios.

However, when the investor is maximizing the Sharpe ratio (for example the constructed portfolio will be complete portfolio) he or she should choose the Portfolio 3 in the TMAI_gr1 ranking rather than the Portfolio 2 in the TMAI_gr2 ranking. Even though the difference in performance is rather small. When the portfolios are compared with the Omega ratio the Portfolio 3 in the TMAI_gr1 ranking is also preferred. However the difference in the performance of the Portfolio 3 in the TMAI_gr1 ranking and the Portfolio 2 in the TMAI_gr2 ranking is rather small. As the result he or she should use 14 financial ratios.

\section{Notes}

1 Proposed by Hellwig (1968).

2 Tarczyński (1994).

3 Tarczyński (2002b), p. 101.

4 See Hadaś-Dyduch (2014); Tarczyński (2002a); Tarczyński (2002b); Tarczyński (1994); Tarczyński, Łuniewska (2003a); Tarczyński, Łuniewska (2003b); Tarczyński, Łuniewska (2004); Łuniewska (2003a); Łuniewska (2003b); 
Łuniewska, Tarczyński (2006); Węgrzyn (2013a); Węgrzyn (2013b); Węgrzyn (2013c); Węgrzyn (2013d); Węgrzyn (2014).

5 Tarczyński (1994); Tarczyński (2002b).

6 See Dyduch (2013).

7 Jerzemowska (2006).

8 Profitability ratios, liquidity ratios, asset turnover ratios (activity ratios or efficiency ratios), financial leverage ratios (debt ratios).

9 Węgrzyn, Analiza korelacji...

${ }^{10}$ Ibidem.

11 Węgrzyn (2013a); Węgrzyn (2014).

${ }^{12}$ It is positively assessed when there are profits (positive values) for the current year $\left(\mathrm{W}_{\mathrm{t} 1}\right)$ and there are losses (negative values) for the base year $\left(\mathrm{W}_{\mathrm{t} 0}\right)$.

${ }^{13}$ Jerzemowska (2006), p. 293.

${ }^{14}$ Ibidem, p. 292.

${ }^{15}$ Ibidem, p. 287.

${ }^{16}$ Ibidem, p. 289.

${ }^{17}$ Financial ratio constructed in similar way to ROS. In the Mzop operating profit is divided by the sales.

${ }^{18}$ Helfert (2003), p. 149.

9 Jerzemowska (2006), p. 137; Helfert (2003), p. 178.

${ }^{20}$ Jerzemowska (2006) p. 138; Helfert (2003), p. 179.

${ }^{21}$ Jerzemowska (2006), p. 138.

22 Waśniewski, Skoczylas (1996).

${ }^{23}$ Ibidem; Waśniewski, Skoczylas (1999).

${ }^{24}$ Waśniewski, Skoczylas (1996); Waśniewski, Skoczylas (1999).

${ }^{25}$ Helfert (2003), p. 157.

${ }^{26}$ Jerzemowska (2006), p. 231.

${ }^{27}$ Ibidem, p. 226.

${ }^{28}$ Defined as a sum of receivables conversion period (in days) and inventory conversion period (in days).

${ }^{29}$ Jerzemowska (2006), p. 235.

${ }^{30}$ Ibidem.

${ }^{31}$ Ibidem.

${ }^{32}$ Waśniewski, Skoczylas (2002), p. 179.

33 Jerzemowska (2006), p. 161.

${ }^{34}$ Hellwig (1968).

${ }^{35}$ Tarczyński, Łuniewska (2003a).

${ }^{36}$ Tarczyński, Łuniewska (2003a).

${ }^{37}$ If there was not an index mWIG40 then an index midWIG is used.

${ }^{38}$ If there was not an index sWIG80 then an index WIRR is used.

${ }^{39}$ In the study are used financial statements from the following data bases prepared by the Notoria Serwis: 1(39)/2003, 3(45)/2004, version 18.30 may 2010, version 20.50 march 2012 .

${ }^{40}$ Financial ratios used to construct this ranking are not significantly correlated inside the same area of financial activity, but they can be significantly correlated with financial ratios from another area of financial activity.

${ }^{41}$ Financial ratios used to construct this ranking are not significantly correlated with any other financial ratio.

${ }^{42}$ Sharpe (1966).

${ }^{43}$ In the Omega ratio the whole returns distribution is used [Shadwick, Keating (2002)]. In order to compute the Omega ratio, it is demanded to choose the break-even point $\mathrm{L}$. Choosing the break-even point $\mathrm{L}$, the investor splits the whole return distribution into two parts: returns above the break-even point $\mathrm{L}$ are considered as gains while returns below 
the break-even point $\mathrm{L}$ are considered as losses. At a given break-even point $\mathrm{L}$, the investor should always prefer the portfolio with the highest value of the Omega ratio [Bertrand, Prigent (2011)]. Moreover, when the Omega ratio is over 1 then there is a higher probability to gain the return over the break-even point $\mathrm{L}$ than the return under the break-even point L. It means that investor should prefer only portfolios with the Omega ratio over 1. As Bacmann and Scholz (2003) point out, the main advantage of the Omega ratio is that it involves all the moments of the return distribution, including skewness and kurtosis.

${ }^{44} \mathrm{pp}$ - percentage points.

\section{References}

Bacmann, J.F. \& Scholz, S. (2003). Alternative performance measures for hedge funds. AIMA Journal, June.

Bertrand, P. \& Prigent, J. (2011). Omega performance measure and portfolio insurance. Journal of Banking \& Finance, 35, 1811-1823.

Dyduch, M. (2013), Bankowe papiery wartościowe strukturyzowane. In: Prognostyczne uwarunkowania ryzyka gospodarczego i społecznego, ed. W. Szkutnik. Studia Ekonomiczne, Zeszyty Naukowe Wydziałowe, 124 (pp. 143-164), Uniwersytet Ekonomiczny w Katowicach.

Hadaś-Dyduch, M. (2014). Zastosowanie metod taksonomiczno-sieciowych w procesie wyznaczania syntetycznego miernika rozwoju inwestycji. In: Metody ilościowe, ed. S. Forlicz. Zeszyty Naukowe Wyższej Szkoły Bankowej we Wrocławiu, 7 (45), 129-142.

Helfert, E.A. (2003). Techniki analizy finansowej. Warszawa: PWE.

Hellwig, Z. (1968). Zastosowanie metody taksonomicznej do typologicznego podziału krajów ze względu na poziom ich rozwoju i strukturę wykwalifikowanych kadr. Przegląd Statystyczny, 4, 307-327.

Jerzemowska, M. (2006). Analiza ekonomiczna w przedsiębiorstwie. Warszawa: PWE.

Łuniewska, M. (2003a). Porównanie parametrów portfeli zbudowanych przy wykorzystaniu wybranych metod WAP z portfelem rynkowym. In: Inwestycje finansowe i ubezpieczenia - tendencje światowe a polski rynek, eds. W. Ronka Chmielowiec, K. Jajuga. Wrocław: Wydawnictwo AE Wrocław.

Łuniewska, M. (2003b). Wykorzystanie metod ilościowych do tworzenia portfela papierów wartościowych. Szczecin: Wydawnictwo Naukowe Uniwersytetu Szczecińskiego.

Łuniewska, M. \& Tarczyński, W. (2006). Metody wielowymiarowej analizy porównawczej na rynku kapitałowym. Warszawa: Wydawnictwo Naukowe PWN.

Shadwick, W. \& Keating, C. (2002). A universal performance measure. Journal of Performance Measurement, 6 (3), 59-84. 
Sharpe, W.F. (1966). Mutual fund performance. Journal of Business, 39 (1), 119-138.

Tarczyński, W. (2002a). Dywersyfikacja ryzyka na polskim rynku kapitałowym. In: Inwestycje finansowe i ubezpieczenia - tendencje światowe a polski rynek, eds. W. Ronka-Chmielowiec, K. Jajuga. Wrocław: Wydawnictwo AE Wrocław.

Tarczyński, W. (2002b). Fundamentalny portfel papierów wartościowych. Warszawa: PWE.

Tarczyński, W. (1994). Taksonomiczna miara atrakcyjności inwestycji w papiery wartościowe. Przegląd Statystyczny, 3, 275-300.

Tarczyński, W. \& Łuniewska, M. (2003a). Dywersyfikacja ryzyka a fundamentalny portfel papierów wartościowych. In: Inwestycje finansowe i ubezpieczenia - tendencje światowe a polski rynek, eds. W. Ronka-Chmielowiec, K. Jajuga. Wrocław: Wydawnictwo AE Wrocław.

Tarczyńki, W. \& Łuniewska, M. (2003b). Wybrane metody wielowymiarowej analizy porównawczej w procesie budowy portfela papierów wartościowych. In: Inwestycje finansowe i ubezpieczenia - tendencje światowe a polski rynek, eds. W. Ronka-Chmielowiec, K. Jajuga. Wrocław: Wydawnictwo AE Wrocław.

Tarczyński, W. \& Łuniewska, M. (2004). Dywersyfikacja ryzyka na polskim rynku kapitałowym. Warszawa: Wydawnictwo Placet.

Waśniewski, T. \& Skoczylas, W. (1996). Analiza przepływów środków pieniężnych - pomocą w zarządzaniu finansami przedsiębiorstwa. Rachunkowość, 6, 271.

Waśniewski, T. \& Skoczylas, W. (1999). Jak korzystać ze sprawozdania z przepływu środków pieniężnych. Rachunkowość, 12, 703.

Waśniewski,T.\& Skoczylas, W. (2002). Teoria i praktyka analizy finansowej w przedsiębiorstwie. Warszawa: Wydawnictwo FRR.

Węgrzyn, T., Analiza korelacji pomiędzy wybranymi wskaźnikami finansowymi na przykładzie spółek publicznych. Article submitted for publication in Studia Ekonomiczne, Zeszyty Naukowe Wydziałowe, UE Katowice [article after a positive review].

Węgrzyn, T. (2013a). Dobór spółek do portfela z wykorzystaniem wskaźników finansowych i ich względnego tempa przyrostu. Analiza w latach 2001-2010. In: Innowacje w bankowości i finansach, eds. J. Harasim, B. Frączek. Studia Ekonomiczne, Zeszyty Naukowe Wydziałowe, Uniwersytet Ekonomiczny w Katowicach, 174, 63-74.

Węgrzyn, T. (2013b). Stock selection based on financial ratios on the Warsaw Stock Exchange. Analysis between 2001 and 2010 (pp. 356-361). European Financial Systems 2013. Proceedings of the 10th International Scientific Conference, Brno: Masaryk University, .

Węgrzyn, T. (2013c). Stock Selection on the Warsaw Stock Exchange Financial Ratios or Profitability Ratios. Analysis between 2001 and 2011, eds. T. Löster, T. Pavelka (pp. 15541564). The 7th International Days of Statistics and Economics, Conference Proceedings, Prague: Libuše Macáková. 
Węgrzyn, T. (2013d). Względne tempo przyrostu wskaźników finansowych $w$ budowie portfeli $w$ latach 2001-2010. In: Problemy społeczno-ekonomiczne $w$ uwarunkowaniach ryzyka i statystycznej nieokreśloności. Metody i modele $w$ rozwoju regionów, ed. W. Szkutnik (pp. 320-333). Katowice: Wydawnictwo UE.

Węgrzyn, T. (2014). Weryfikacja zastosowania metody porządkowania liniowego Hellwiga w kontekście doboru spółek do portfela. Analiza w latach 2001-2010. Nauki o Finansach, 1 (18), 87-97. 